Vol.1 No.2 Desember 2019

\section{Keterbukaan Informasi dalam Pelayanan Perizinan di Dinas Perizinan dan Penanaman Modal Daerah Istimewa Yogyakarta}

\section{Verena Grescentia T.}

Program Studi Magister Ilmu Komunikasi, Universitas Atma Jaya

Yogyakarta, Indonesia

*Korespondensi Penulis. E-mail: verena.gresce@gmail.com

\begin{abstract}
Abstrak
Penelitian ini menganalisis keterbukaan informasi publik yang diterapkan oleh Dinas Perizinan dan Penanaman Modal DIY terutama dalam informasi perizinan. Penelitian ini diterapkan dengan menggunakan metode deskriptif kualitatif dengan pengumpulan data melalui wawancara yang dilaksanakan di Dinas Perizinan dan Penanaman Modal DIY. Selain itu, Dinas Perizinan dan Penanaman Modal DIY memiliki sistem pelayanan yang dapat dijadikan acuan dalam memberikan informasi terkait perizinan. Hasil yang diperoleh dalam penelitian ini keterbukaan informasi, pelayanan perizinan dan aspek komunikasi yang dilaksanakan oleh Dinas Perizinan dan Penanaman Modal DIY dilihat dari aspek pelayanan perizinan dan komunikasi yang diterapkan kepada publik.
\end{abstract}

Kata kunci: Keterbukaan Informasi, Pelayanan Perizinan, Dinas Perizinan dan Penanaman Modal DIY

\section{Information Disclosure in Licensing Services at the Licensing and Investment Office of Yogyakarta Special Region}

\begin{abstract}
This study analyzes how public information disclosure is applied Licensing and Investment Office of Yogyakarta Special Region, especially in licensing information. This research was applied using qualitative descriptive methods by collecting data through interviews carried out in the Licensing and Investment Office of Yogyakarta Special Region. In addition, Licensing and Investment Office of Yogyakarta Special Region has a service system that can be used as a reference in providing licensing related information. The results obtained in this study are information disclosure, licensing services and communication aspects carried out by Licensing and Investment Office of Yogyakarta Special Region seen from the aspects of licensing and communication services applied to the public.
\end{abstract}

Keywords: Information Disclosure, Licensing Services, Licensing and Investment Office of Yogyakarta Special Region

\section{A. PENDAHULUAN}

Keterbukaan informasi di era perkembangan teknologi diatur pada Undang-Undang Nomor 14 Tahun 2008 tentang Keterbukaan Informasi Publik. Pemerintah memiliki tugas penting dalam menyampaikan informasi yang dibutuhkan oleh masyarakat. Tugasnya adalah menyediakan dan memberikan pelayanan informasi. Melalui peraturan ini, pemerintah menjalankan perannya dan berorientasi pada pelayanan rakyat yang sebaik-baiknya. Dalam 
pelaksanaannya, keterbukaan informasi mengalami hambatan.

Problematika yang pertama adalah terhambatnya penyampaian informasi kepada masyarakat sebagai akibat dari ketatnya prosedur birokrasi. Permohonan informasi yang dimintakan memakan waktu lama untuk mendapatkan jawaban. Proses perolehan izin yang melalui banyak kontrol secara berantai dan aturan-aturan ketat yang mengharuskan masyarakat melewati banyak sekat-sekat formalitas (Setiawan, 2004). Ketidakjelasan prosedur permohonan informasi menjadi kendala bagi pemohon untuk mengajukan informasi. Akibatnya masyarakat enggan mengajukan permohonan informasi kepada pemerintah.

Problematika kedua ialah minimnya sosialisasi informasi terkait kemudahan dalam mengakses informasi. Pemohon informasi kesulitan mengenai cara menyampaikan permohonan informasi. Akibatnya, pemerintah yang harus turun tangan memberikan sosialisasi kepada publik. Informasi untuk publik idealnya mudah diakses oleh masyarakat. Realitanya, masyarakat harus memohonkan informasi pada instansi pemerintah.

Problematika ketiga ialah peningkatan kebutuhan masyarakat yang justru seringkali tidak sejalan dengan kemampuan sumber daya yang dimiliki oleh pemerintah dalam menyediakan semua tuntutan masyarakat (Imbaruddin, 2019). Masyarakat semakin bertumbuh dan menuntut untuk peningkatan layanan publik. Pemerintah belum siap mengakomodir segala kebutuhan masyarakat. Tentu ini menjadi latar belakang ketidakpuasan masyarakat terhadap pelayanan publik.

Keterbukaan informasi membuka ruang pengetahuan, edukasi dan memberikan kesaradan bagi masyarakat. Keterbukaan informasi memiliki tujuan sebagai sarana kontrol publik terhadap perilaku penyelenggara negara dan penyelenggaraan negara, mendorong akuntabilitas proses penyelenggaraan dan penyelenggara negara, prasyarat partisipasi yang efektif dalam pengambilan keputusan, mencegah mal-administrasi dan korupsi dan memberikan data yang kuat untuk pembelaan, bila seseorang terlibat dalam masalah hukum (Sastro, dkk, 2010). Dengan adanya keterbukaan informasi, pemerintah menjalankan prinsip transparansi. Prinsip transparansi membuka ruang partisipasi bagi masyarakat untuk mengawasi. Masyarakat dapat memberikan masukan terkait dengan penyelenggaraan negara dan bertugas memberikan pengawasan di lapangan.

Badan publik memiliki kewajiban memberikan informasi terutama berkaitan dengan penyelenggaraan negara sesuai dengan definisi yang tercantum dalam Undang-Undang Nomor 14 Tahun 2008 tentang Keterbukaan Informasi Publik. Badan publik semestinya menyediakan informasi yang dapat diakses oleh publik. 
Melalui penyediaan ini, masyarakat dapat mengaksesnya untuk mendapatkan informasi. Badan publik menyediakan kanal atau ruang yang mudah dan cepat untuk dimanfaatkan oleh masyarakat. Badan publik memaksimalkan peran Pejabat Pengelola Informasi dan Dokumentasi (PPID) yang dimiliki oleh masing - masing instansi.

Setiap instansi atau lembaga pemerintah menunjuk Pejabat Pengelola Informasi dan Dokumentasi (PPID) untuk menyediakan informasi yang disampaikan kepada publik sesuai dengan standar. Dalam hal ini PPID utama menjadi kewenangan instansi penyedia informasi. PPID utama mempunyai tugas merencanakan, mengorganisasikan, melaksanakan, dan mengevaluasi pelaksanaan kegiatan pengelolaan dan pelayanan informasi sesuai dengan Peraturan Gubernur Daerah Istimewa Yogyakarta Nomor 52 Tahun 2018 tentang Pedoman Pengelolaan Informasi Publik. PPID pembantu berada pada masing-masing instansi pemerintah. Peran PPID Pembantu terletak pada penyediaan informasi bersifat sektoral sesuai kewenangan dan menyokong peran PPID Utama. Salah satu tugas PPID Pembantu ialah penyediaan infomasi terkait pelayanan perizinan.

Pembahasan mengenai informasi perizinan berkaitan dengan terbitnya Peraturan Pemerintah Nomor 24 Tahun 2018 tentang Pelayanan Perizinan Berusaha Terintegrasi Secara Elektronik.
Melalui peraturan tersebut, informasi terkait perizinan secara umum dapat diklasifikasikan. Selain itu, peraturan tersebut menjadi landasan diberlakukannya perizinan secara elektronik. Akses dan informasi disediakan secara luas sehingga masyarakat dapat menggunakannya secara mandiri.

Di era perkembangan teknologi arus informasi melalui berbagai media yang dapat diakses oleh setiap individu. Informasi publik disampaikan melalui website resmi yang dimiliki oleh instansi. Media sosial dihadirkan dalam rangka menjangkau masyarakat terutama mengakomodir kebutuhan informasi. Masyarakat mengakses media sosial yang dimiliki oleh pemerintah Daerah Istimewa Yogyakarta salah satunya akun twitter @humas_jogja yang dikelola oleh Dinas Komunikasi dan Informatika DIY. Begitu juga dengan website serta alamat email dari PPID Utama melalui alamat ppid.jogjaprov.go.id yang dapat diakses oleh pemohon informasi.

Beberapa penelitian terkait dengan keterbukaan informasi publik dilaksanakan oleh Setiaman, Sugiana, \& Narotama (2013) yang menganalisis keterbukaan publik dari aspek masyarakat kota Bandung. Terdapat dua analisis dalam penelitian ini yaitu analisis kuantitatif dan kualitatif. Keterbukaan informasi dipandang dari optimalisasi lembaga publik, konten informasi, birokrasi dan penyampaian informasi kepada publik. Selain itu penelitian dari Indah \& Hariyanti (2018) yang 
menganalisis implementasi keterbukaan informasi publik pada Dinas Kominfo Kota Tasikmalaya. Pada penelitian tersebut, dinas memberikan akses komunikasi yang luas terutama dengan pemanfaatan media sosial, komunikasi secara langsung dan menjalin hubungan baik dengan media. Selain itu, penting dalam membangun komunikasi dengan dinas-dinas lain dalam rangka memberikan informasi terbaik. Terakhir, aspek birokrasi dan penerapan standar operasional prosedur yang dapat mempengaruhi implementasi keterbukaan publik.

Penelitian ini menganalisis tentang pelaksanaan keterbukaan informasi yang diterapkan oleh Dinas Perizinan dan Penanaman Modal DIY dalam mengatasi problematika. Prinsip terkait pelaksanaan tata kelola perusahaan yang baik meliputi aspek transparansi dan akuntabilitas. Melalui penelitian ini, peneliti ingin menganalisis problematika yang terjadi dikaitkan dengan keterbukaan informasi dengan menggunakan teori tata kelola perusahaan yang baik.

\section{B. TEORI (Literature Review)}

Penelitian ini menggunakan teori birokrasi dan tata kelola perusahaan yang baik (Good Corporate Governance). Birokrasi menurut Weber dalam Yusriadi (2018) mendasarkan diri pada hubungan antara kewenangan menempatkan dan mengangkat pegawai bawahan dengan menentukan tugas dan kewajiban di mana perintah dilakukan secara tertulis. Hubungan kewenangan dan promosi kepegawaian diatur melalui regulasi. Birokrasi mempunyai berbagai sifat yang dapat penting yaitu adanya spesialisasi (pembagian kerja), adanya hierarki yang berkembang, adanya suatu sistem dari suatu prosedur dan aturanaturan, adanya hubungan-hubungan kelompok yang bersifat impersonalitas, dan adanya promosi dan jabatan yang berdasarkan atas kecakapan (Mustapa, 2017). Hierarki berkaitan dengan struktur yang memiliki pengaturan sistem mekanisme dan prosedur. Struktur menentukan cara pengambilan keputusan secara sistematis dan konsisten.

Birokrasi bersifat formal menyebabkan mekanisme dan prosedural terlaksana secara kaku. Di samping itu, birokrasi memiliki tugas yaitu tugas administratif, tugas memberikan nasehat kebijakan, tugas artikulasi dan agregasi kepentingan dan tugas menjaga stabilitas organisasi (Mustapa, 2017). Berdasarkan tugas tersebut, birokrasi bisa mengelola mekanisme organisasi pemerintahan. Lemahnya adalah birokrasi mampu menangani hal-hal yang yang menyangkut kehidupan masyarakat dan rentan pada instruksi kekuasaan sehingga posisinya terlalu sulit untuk digantikan. Pengambilan keputusan yang didasarkan pada struktural yang mengakibatkan memakan waktu lama dan tidak akurat.

Penyederhanaan birokrasi pemerintah dilakukan untuk 
mengarahkan organisasi secara proporsional. Penataan kelembagaan dikaitkan dengan pengaturan birokrasi. Instansi membutuhkan visi dan misi yang jelas, struktur organisasi, serta eksekusinya. Penataan kebutuhan sarana dan prasarana serta sumber daya manusia dilakukan dalam rangka menyederhanakan sistem yang berjenjang yaitu birokrasi. Dalam melaksanakan birokrasi juga didukung aspek transparansi dan akuntabilitas yang menjadi prinsip dari tata kelola perusahaan yang baik.

Tata kelola perusahaan yang baik adalah suatu sistem yang mengelola dan mengawasi proses pengendalian usaha yang berjalan secara berkesinambungan untuk menaikkan nilai dan sebagai bentuk pertanggungjawaban kepada pemangku kepentingan dan masyarakat (Franita, 2018). Penerapan tata kelola perusahaan yang baik dilaksanakan di lingkungan Badan Usaha Milik Negara (BUMN). Terdapat prinsip-prinsip mengenai tata kelola perusahaan yang baik yaitu tranparansi, kemandirian, akuntabilitas, pertanggungjawaban dan kewajaran (Sudharmono, 2004).

Berkaitan dengan pelayanan publik, beberapa prinsip yang penting untuk dilaksanakan pada instansi adalah transparansi dan akuntabilitas. Transparansi berkaitan dengan keterbukaan dalam melaksanakan proses pengambilan keputusan dan keterbukaan dalam mengemukakan informasi materiil dan relevan mengenai perusahaan
(Sudharmono, 2004). Dalam prinsip transparansi berkaitan dengan aliran informasi yang bebas baik di dalam maupun di antara organisasi termasuk masyarakat (Bennis, Goleman, \& O'Toole, 2009). Transparansi dari segi informasi berkaitan dengan penyampaian pesan kepada orang yang tepat dan sesuai peruntukkan. Hal ini membutuhkan komitmen dari pemimpin yang mampu mengawal proses tersebut. Pelaksanaan transparansi disesuaikan dengan kebutuhan, terlalu terbuka akan membahayakan dan terlalu tertutup menjadi bumerang.

Transparansi dalam pelayanan publik memiliki porsi penting karena keterbukaan informasi menjadi kebutuhan masyarakat. Di sisi lain, pelaksanaan transparansi tidak semudah itu. Beberapa eksekutif menikmati kesenangan saat mengetahui informasi penting dan menjauhkannya dari para bawahan (Bennis et al., 2009). Hal ini menghambat aliran informasi yang seharusnya dapat disajikan kepada publik. Transparansi membantu organisasi menyampaikan aktivitasnya baik dari internal maupun eksternal.

Akuntabilitas yaitu kejelasan fungsi, pelaksanaan dan pertanggungjawaban organ sehingga pengelolaan perusahaan terlaksana secara efektif (Sudharmono, 2004). Dalam pelaksanaan akuntabilitas dibutuhkan mekanisme informal terutama sektor publik. Akuntabilitas publik adalah pendekatan, 
mekanisme, dan praktik-praktik yang digunakan oleh pemangku kepentingan (stakeholders) untuk menjamin bahwa kinerja pelayanan publik yang diberikan oleh pegawai atau lembaga pemerintah sesuai dengan harapan masyarakat (Imbaruddin, 2019). Dengan akuntabilitas, penyediaan layanan publik dapat sesuai dengan jenis layanan yang diharapkan dan dari segi kualitas mencukupi.

Akuntabilitas dapat menjadi instrumen agar pegawai pemerintah berperilaku dan bertindak sesuai dengan keinginan masyarakat (Patarai, 2015). Kuncinya adalah ketugasan dari pegawai untuk melayani masyarakat dan bertanggung jawab kepada masyarakat. Akuntabilitas menjamin terpenuhinya kebutuhan masyarakat dengan memberikan layanan publik. Dikaitkan dengan pelayanan publik, akuntabilitas merupakan bentuk pertanggungjawaban pemberi layanan publik dalam melaksanakan tugas pokok dan fungsinya.

\section{METODE}

Penelitian ini menggunakan metode kualitatif yang memberikan gambaran atau deskripsi dalam penyajian data. Penelitian kualitatif merupakan penelitian yang menghasilkan data secara deskriptif berupa kata-kata tertulis maupun lisan dari orang-orang dan perilaku yang diamati menurut Bodgan Taylor dalam Moleong (2010). Langkah pengumpulan datanya menggunakan wawancara secara mendalam, dan studi pustaka. Dinas Perizinan dan Penanaman Modal DIY dipilih sebagai salah satu badan publik yang memberikan layanan publik kepada masyarakat terutama perizinan berusaha. Dinas Perizinan dan Penanaman Modal DIY memberikan layanan perizinan kepada masyarakat. Perizinan berusaha menjadi dasar operasional bagi pemilik usaha dalam menjalankan kegiatannya. Pemilihan person dalam wawancara didasarkan pada kebutuhan akan informasi mengingat jumlah personel dari Dinas Perizinan dan Penanaman Modal DIY dari 50 orang. Person yang diwawancarai adalah pejabat struktural dalam pelayanan perizinan dan bidang yang menangani data dan informasi beserta staf yang menangani. Selain itu wawancara juga dilakukan dengan petugas front office terutama proses komunikasi langsung antara front office dan pemohon izin. Teknik analisis data yang digunakan ialah melakukan pengecekan dan perbandingan data yang telah dikumpulkan melalui proses wawancara dan studi pustaka. Data yang telah didapatkan sebelumnya dikumpulkan dan diklasifikasikan. Setiap data yang masuk dibandingkan dan dianalisis.

\section{HASIL DAN PEMBAHASAN}

Pada penelitian ini menghasilkan beberapa poin penting. Keterbukaan informasi berkaitan dengan birokrasi dan tranparansi. Akuntabilitas berkaitan dengan tugas dan fungsi instansi pelayan publik. 
Vol.1 No.2 Desember 2019

Komunikasi sebagai jembatan bagi pelaksanaan keduanya. Bagian pertama akan membahas mengenai keterbukaan informasi.

\section{Keterbukaan Informasi}

Informasi yang disampaikan kepada publik melalui berbagai media yang dimiliki oleh setiap instansi. Keterbukaan informasi merupakan salah satu ciri penting negara demokratis yang menjunjung tinggi kedaulatan rakyat untuk mewujudkan penyelenggaraan negara yang baik sesuai dengan Undang-Undang 14 Tahun 2008 tentang Keterbukaan Informasi Publik. Keterbukaan informasi ialah cara publik dalam mengawasi kinerja pemerintahan terutama yang menyangkut kepentingan masyarakat luas. Dalam rangka memenuhi ketentuan dalam peraturan keterbukaan informasi publik, setiap instansi wajib menyediakan informasi yang dapat diakses dengan mudah oleh masyarakat secara luas.

Informasi menjadi hak bagi setiap individu yang telah dijamin dalam Undang-Undang. Dalam mengajukan permohonan informasi, prosedur dijalankan melalui tahaptahap sesuai dengan peraturan. Jawaban permohonan informasi wajib ditindaklanjuti maksimal 10 (sepuluh) hari kerja sejak permohonan teregistrasi. Instansi publik memiliki kesempatan untuk memberikan jawaban informasi sesuai dengan jangka waktu maksimal. Permohonan informasi disampaikan kepada PPID secara langsung maupun tidak langsung.
Mekanisme permohonan secara langsung tetap dicatat oleh PPID di Dinas Perizinan dan Penanaman Modal DIY. Dalam penyampaian secara tertulis proses melalui surat permohonan informasi yang akan ditindaklanjuti oleh PPID.

Keterbukaan informasi yang dilaksanakan di Dinas Perizinan dan Penanaman Modal DIY berkaitan dengan prinsip transparansi. Rata rata pemohon izin yang mendapatkan pelayanan di Dinas Perizinan dan Penanaman Modal DIY sebanyak 10 orang per harinya. Informasi disampaikan kepada pemohon informasi mengenai mekanisme perizinan yang menjadi kewenangan dari Dinas Perizinan dan Penanaman Modal DIY. Informasi mengenai biaya terkait proses pelayanan perizinan juga disampaikan. Informasi juga tersaji dalam website Dinas Perizinan dan Penanaman Modal DIY.

Dinas Perizinan dan Penanaman Modal DIY telah menyusun daftar informasi yang dikecualikan yaitu adalah data pemohon dan data pemohon pengaduan. Kedua informasi tersebut tidak dapat dipublikasikan secara luas kecuali disampaikan pada aparat penegak hukum dan instansi yang mengawasi izin. Data pemohon izin termasuk dalam kategori pelaku usaha sesuai peraturan keterbukaan informasi publik. Data pemohon izin masuk ke dalam kategori informasi pribadi yang dilindungi oleh peraturan keterbukaan informasi publik. Daftar informasi yang dikecualikan disampaikan kepada PPID Utama 
pada Dinas Komunikasi dan Informatika DIY. Pengumpulan data ini sebagai dasar PPID Utama dalam mengklasifikasikan informasi yang dapat diakses publik dan informasi yang tertutup. Informasi yang dikecualikan disusun pada Lembar Pengujian Konsekuensi yang telah disepakati bersama.

Peran PPID Pembantu di Dinas Perizinan dan Penanaman Modal DIY belum optimal sesuai dengan tugas pokok dan fungsinya. Permohonan informasi dan data yang masuk didisposisi kepada bidang pengaduan dan kemudahan berusaha Dinas Perizinan dan Penanaman Modal DIY. Hal ini berdampak pada fungsi PPID yang tidak mengetahui apabila terdapat permohonan informasi publik. Penyelesaian permohonan informasi dilaksanakan oleh bidang pengaduan dan kemudahan berusaha. Kesalahan dalam disposisi diakibatkan tugas dan fungsi yang tercantum dalam Peraturan Gubernur Daerah Istimewa Yogyakarta Nomor 66 Tahun 2018 tentang Kedudukan Susunan Organisasi Tugas Fungsi dan Tata Kerja Dinas Perizinan dan Penanaman Modal. Seksi pengaduan mempunyai fungsi salah satunya ialah dalam pengelolaan informasi layanan sehingga mendapat disposisi surat dalam rangka kebutuhan informasi.

Keterbukaan informasi yang menjadi kewajiban badan publik belum dapat dipahami dikarenakan tugas dan fungsi peran PPID belum dicantumkan pada setiap aturan mengenai tugas dan fungsi. Selain itu, esensi dari keterbukaan informasi belum dipahami sebagai tanggung jawab yang penyampaiannya hanya formalitas. Tidak hanya itu, bidang pelayanan perizinan Dinas Perizinan dan Penanaman Modal DIY turut mendapat permohonan informasi dari pemohon secara langsung.

Informasi seputar pelayanan perizinan baik berupa mekanisme hingga jangka waktu penerbitan izin menjadi informasi yang disampaikan kepada publik. Ketugasan PPID Pembantu yang optimal dapat membantu dan mendukung penyampaian kebutuhan informasi pada publik. Pemohon informasi tidak perlu mengarah ke bidang tertentu untuk mendapatkan informasi dan dapat diselesaikan oleh peran PPID.

Informasi yang bersifat terbuka ialah profil kelembagaan Dinas Perizinan dan Penanaman Modal DIY, program atau kegiatan yang dilaksanakan, realisasi investasi, mekanisme permohonan izin, daftar layanan izin, standar operasional prosedur pelayanan perizinan, data jumlah permohonan izin masuk dan izin yang diterbitkan, jumlah pengaduan yang masuk dan yang telah tertangani, mekanisme penanganan pengaduan, angka indeks kepuasan masyarakat, daftar kerjasama Pemerintah Daerah Istimewa Yogyakarta, dan potensi investasi Daerah Istimewa Yogyakarta.

\section{Akuntabilitas}

Akuntabilitas berkaitan dengan pertanggungjawaban instansi kepada 


\section{Vol.1 No.2 Desember 2019}

publik salah satu pelaksanaan pelayanan publik. Pelayanan publik merupakan kegiatan atau rangkaian kegiatan dalam rangka pemenuhan kebutuhan pelayanan sesuai dengan peraturan perundang-undangan bagi setiap warga negara dan penduduk atas barang, jasa, dan/atau pelayanan administratif yang disediakan oleh penyelenggara pelayanan publik sesuai dengan ketentuan umum Undang-Undang Nomor 25 Tahun 2009 tentang Pelayanan Publik. Pelayanan perizinan merupakan salah satu bagian dalam pelayanan publik.

Pelayanan perizinan merupakan salah satu tugas dan fungsi yang dijalankan Perizinan dan Penanaman Modal DIY. Perizinan adalah pemberian dokumen dan bukti legalitas persetujuan dari pemerintah kepada seseorang atau pelaku usaha/kegiatan tertentu sesuai dengan ketentuan peraturan perundang-undangan sebagaimana tercantum dalam Peraturan Menteri Dalam Negeri Republik Indonesia Nomor 138 Tahun 2017 tentang Penyelenggaraan Pelayanan Terpadu Satu Pintu Daerah. Instansi penerbit produk izin memberikan pelayanan perizinan dalam rangka memberikan fasilitas pemohon izin. Pemberian layanan dimulai dari tahap permohonan hingga penyelesaian berupa hasil produk layanan. Tidak hanya itu, layanan diberikan berupa informasi yang disampaikan kepada masyarakat yang hadir dalam rangka mendapatkan syarat dan langkah perizinan.

\begin{tabular}{lcr}
\multicolumn{1}{c}{ Pelayanan } & dalam & rangka \\
memberikan & dokumen & izin \\
membutuhkan & tanggung & jawab
\end{tabular}
instansi kepada masyarakat. Sebagai institusi penyelenggara pelayanan publik, Dinas Perizinan dan Penanaman Modal DIY memiliki pedoman penyelenggaraan pelayanan yaitu standar pelayanan yang mengatur mekanisme dan prosedur terkait layanan publik. Standar pelayanan merupakan tolok ukur yang dipergunakan sebagai pedoman penyelenggaraan pelayanan dan acuan penilaian kualitas pelayanan sebagai kewajiban dan janji penyelenggara kepada masyarakat dalam rangka pelayanan yang berkualitas, cepat, mudah, terjangkau, dan terukur sesuai dengan Peraturan Menteri Pendayagunaan Aparatur Negara dan Reformasi Birokrasi Nomor 15 Tahun 2014 tentang Pedoman Standar Pelayanan. Pelaksanaan mekanisme pelayanan sesuai dengan standar pelayanan mewujudkan rasa tanggung jawab pemerintah kepada masyarakat.

Jenis perizinan yang dilayani sesuai dengan Peraturan Gubernur Nomor 67 Tahun 2019 tentang Penyelenggaraan Pelayanan Terpadu Satu Pintu terdiri dari 19 sektor yaitu penanaman modal, koperasi, perdagangan, perindustrian, kesehatan, perhubungan, tenaga kerja, sosial, kehutanan dan perkebunan, lingkungan hidup, energi sumber daya mineral, pekerjaan umum, pendidikan, pertanian, kelautan dan perikanan, kebudayaan, pariwisata, pertanahan 
tata ruang dan kesatuan bangsa dan politik. Penerapan izin melalui sistem Online Single Submission (OSS) sejak diterbitkannya Peraturan Pemerintah Nomor 24 Tahun 2018 tentang Pelayanan Perizinan Berusaha Terintegrasi Secara Elektronik. Produk izin diterbitkan melalui lembaga OSS untuk dan atas nama pemerintah yaitu menteri, pimpinan lembaga, gubernur atau bupati/wali kota. Produk izin disampaikan kepada pelaku usaha dengan proses yang disampaikan melalui OSS.

Berdasarkan jenis pelayanan yang diberikan oleh Dinas Perizinan dan Penanaman Modal DIY tidak semua sektor dilayani menggunakan aplikasi OSS. Empat sektor yang dilayani dengan menggunakan berkas permohonan manual ialah sektor energi sumber daya mineral, pekerjaan umum, sosial dan kebudayaan. Petugas front office mengarahkan permohon izin ke dalam kategori perizinan melalui OSS atau permohonan izin secara manual. Dasar pembagian yang tercantum pada pembagian kewenangan propinsi dan kabupaten atau kota sesuai Undang-Undang Nomor 23 Tahun 2014 tentang Pemerintahan Daerah dan peraturan mengenai OSS. Informasi seputar layanan disampaikan oleh petugas front office dan petugas informasi yang berada di ruang layanan. Petugas front office menyampaikan prosedur dan mekanisme permohonan izin dan menjawab pertanyaan dari pemohon izin.
Dalam menjalankan pelayanan perizinan, Dinas Perizinan dan Penanaman Modal DIY berpegang pada maklumat pelayanan. Maklumat pelayanan sesuai dengan UndangUndang Nomor 25 Tahun 2009 tentang Pelayanan publik merupakan pernyataan tertulis yang berisi keseluruhan rincian kewajiban dan janji yang terdapat dalam dalam standar pelayanan. Setiap petugas front office emberikan layanan sesuai dengan maklumat pelayanan. Dinas Perizinan dan Penanaman Modal DIY memiliki maklumat

"dengan ini kami menyatakan sanggup menyelenggarakan pelayanan sesuai standar pelayanan yang telah ditetapkan dan apabila tidak menepati janji, kami siapa menerima sanksi sesuai peraturan perundang-undangan yang berlaku".

Petugas front office dibekali pengetahuan mengenai dasar hukum perizinan dari berbagai sektor. Tujuannya ialah dapat memberikan informasi yang valid kepada pemohon atau masyarakat umum seputar pelayanan perizinan. Komitmen dalam melayani permohonan izin menjadi hal yang utama dan diterapkan oleh front office Dinas Perizinan dan Penanaman Modal DIY. Pelaksanaan tugas setiap personel didasarkan pada standar pelayanan.

Pemohon informasi dapat mengunjungi akun twitter dari DPPM DIY ialah @jogjainvest dan akun instagram ialah jogja_invest dalam rangka mengajukan permohonan 
informasi. Media sosial digunakan sebagai sarana penyampaian informasi termasuk layanan yang diberikan oleh Dinas Perizinan dan Penanaman Modal DIY. Layanan izin diberikan juga pada saat Dinas Perizinan dan Penanaman Modal DIY mengikuti kegiatan pameran yang diselenggarakan oleh pemerintah daerah. Penempatan personel di Mall Pelayanan Publik Pemerintah Kabupaten Kulon Progo dilakukan dalam rangka penyampaian informasi terkait pelayanan perizinan.

Media informasi melalui website dan media sosial secara rutin memberikan informasi terkait pelayanan perizinan. Petugas front office dapat memberikan informasi yang dibutuhkan oleh pemohon izin terkait pelayanan perizinan dan melayani konsultasi permasalahan perizinan. Data layanan izin dan prosedurnya disampaikan kepada pemohon sebagai informasi awal. Di luar layanan yang menjadi kewenangan Dinas Perizinan dan Penanaman Modal DIY dijelaskan kepada pemohon mengenai solusi dan langkah yang dapat dijalankan sesuai dengan ketentuan.

\section{Komunikasi}

Penyampaian informasi kepada pemohon informasi melalui proses komunikasi baik secara langsung maupun tidak langsung. Petugas front office Dinas Perizinan dan Penanaman Modal DIY menyampaikan informasi secara langsung kepada pemohon yang meminta informasi terkait layanan perizinan. Mekanisme perizinan juga dijelaskan dalam diskusi ini terutama bagi pemohon yang menyerahkan berkas perizinan. Sebagai representatif dari sebuah instansi, petugas front office dibekali dengan kemampuan komunikasi yang baik. Selain itu, mampu menganalisis permasalahan yang dialami oleh pemohon dan memberikan saran dan solusi kepada pemohon. Permohonan informasi secara tidak langsung memanfaatkan media seperti surat resmi, surat elektronik, dan pemanfaatan media sosial dan website resmi dari Dinas Perizinan dan Penanaman Modal DIY.

Aspek komunikasi tidak hanya dibebankan kepada petugas front office namun seluruh personel di Dinas Perizinan dan Penanaman Modal DIY. Komitmen pemimpin untuk menepati maklumat dan menjalankan standar pelayanan dan standar operasional prosedur (SOP) dalam rangka menjalankan tugas dan wewenang perizinan. Komitmen pimpinan dalam rangka menjaga ritme dan memberikan pelayanan terbaik terwujud dalam pemrosesan informasi terutama koordinasi dengan struktural di bawahnya. Kendala-kendala diselesaikan dengan melakukan rapat koordinasi, penerapan informasi dengan menyediakan ruang atau media dalam rangka mendukung perkembangan pemrosesan perizinan melalui sistem online.

Penentuan terhadap informasi yang bersifat terbuka dan informasi yang bersifat tertutup melalui proses koordinasi yang mengakomodir 
Vol.1 No.2 Desember 2019

informasi dari setiap bidang. Informasi didapatkan dengan menggelar rapat koordinasi bersama bidang pelayanan perizinan dan non perizinan, bidang pengaduan dan kemudahan berusaha, bidang promosi dan kerjasama luar negeri dan bidang pengembangan dan pengendalian penanaman modal Dinas Perizinan dan Penanaman Modal DIY. Data dijadikan dasar dalam penyusunan daftar informasi yang dikecualikan dan disampaikan kepada Dinas Komunikasi dan Informatika DIY sebagai PPID Utama. Dalam pengumpulan informasi yang dikecualikan dengan menyertakan alasan darri segi regulasi. Data pemohon izin termasuk dalam daftar informasi yang dikecualikan dengan dasar informasi berkaitan dengan hak-hak pribadi.

Dinas Perizinan dan Penanaman Modal memberikan layanan informasi terutama kepada pemohon informasi terwujud dalam pelayanan sehari-hari. Pemohon yang mengajukan pertanyaan atau membutuhkan konfirmasi mengenai progres perizinan dapat dilayani pada loket pengajuan atau permohonan berkas sesuai sektor. Pemohon yang mengajukan pertanyaan mengenai mekanisme pelayanan perizinan dapat dilayani oleh loket pengajuan atau permohonan berkas sesuai sektor. Kendala yang dialami oleh petugas front office dalam rangka penyampaian informasi kepada publik disampaikan kepada atasan langsung. Pelayanan yang memberikan kemudahan kepada pemohon memberikan dampak pada penilaian indeks kepuasan masyarakat. Indikator dalam indeks kepuasan masyarakat terdiri dari persyaratan izin, kemudahan prosedur layanan, kecepatan pelayanan, kewajaran biaya/tarif, kemampuan petugas, perilaku petugas, kualitas sarana dan prasarana, dan penanganan pengaduan. Kemudahan prosedur layanan yang diberikan kepada pemohon izin memberikan jawaban atas pertanyaan yang disampaikan dan memberikan dampak pada pengisian kuesioner indeks kepuasan masyarakat.

Peran komunikasi berfungsi sebagai penyelesaian permasalahan yang terjadi dalam rangka penyampaian informasi. Permasalahan yang terjadi terutama berkaitan dengan kegiatan usaha membutuhkan koordinasi dengan dinas lain sesuai dengan sektor. Komunikasi dengan personel dengan dinas yang memahami dari segi teknis dapat menyelesaikan permasalahan. Selain itu dapat mengembangkan kemampuan dan kapasitas petugas front office sehingga dapat menghadapi permasalahan yang sama. Kendala yang dialami ialah kekurangan personel dalam rangka memberikan layanan informasi secara maksimal kepada pemohon informasi dan pemohon izin. Sumber daya manusia yang berada di lingkup pelayanan memiliki beban dalam rangka penyelesaian perizinan sesuai dengan standar operasional prosedur. 


\section{E. SIMPULAN DAN SARAN}

Dalam rangka menjalankan keterbukaan informasi yang didasarkan pada Undang - Undang Nomor 14 Tahun 2008 tentang Keterbukaan Informasi Publik, Dinas Perizinan dan Penanaman Modal DIY mengarah pada aspek pelayanan informasi terkait perizinan. Publik sebagai pemohon izin membutuhkan informasi mengenai mekanisme, perkembangan izin dan klasifikasi perizinan sesuai sektor. Prinsip transparansi tercermin dalam keterbukaan informasi. Dinas Perizinan dan Penanaman Modal DIY memiliki informasi yang dikecualikan. Akuntabilitas tercermin dalam pelaksanaan pelayanan sesuai dengan standar pelayanan publik. Ketugasan pejabat pengelola informasi dan dokumentasi pada setiap instansi belum berfungsi secara optimal. Realitanya, permohonan informasi disampaikan kepada unit atau bidang lain.

Keterbukaan informasi didasarkan pada peraturan yang ada menjadi kewajiban untuk dijalankan pada setiap instansi pemerintahan. Khususnya di Dinas Perizinan dan Penanaman Modal DIY wajib memberikan layanan data dan informasi berkaitan dengan perizinan. Komitmen pimpinan dalam menjalankan tugas utama dengan keterbatasan terutama dalam memberikan layanan informasi. Setiap personel dari Dinas Perizinan dan Penanaman Modal DIY mendukung komitmen dalam memberikan layanan publik terbaik kepada masyarakat sesuai dengan tugas dan fungsi yang tercantum dalam peraturan gubernur.

Informasi yang disampaikan dalam pelayanan perizinan bersifat terbuka dan dapat diakses. Pemerintah sesuai dengan tugasnya menyediakan kanal-kanal agar dapat diakses oleh masyarakat. Instansi perizinan perlu menyempurnakan sarana dan prasarana untuk memudahkan pemohon informasi. Perlunya penyederhanaan permohonan informasi dari segi waktu pemrosesan sehingga tidak memakan waktu lama. Penyiapan juga dilakukan pada sumber daya manusia yang melayani pemohon informasi.

\section{Daftar Pustaka}

Bennis, W., Goleman, D., \& O’Toole, J. (2009). Transparansi: Bagaimana Pemimpin Menciptakan Budaya Keterbukaan (I. Yovita, ed.). Jakarta: Libri.

Franita, R. (2018). Mekanisme Good Corporate Governance dan Nilai Perusahaan: Studi Untuk Perusahaan Telekomunikasi. Medan: Lembaga Penelitian dan Penulisan Ilmiah Aqli.

Imbaruddin, A. (2019). Birokrasi Akuntabilitas Kinerja. Yogyakarta: Deepublish.

Indah, T., \& Hariyanti, P. (2018). Implementasi Kebijakan Keterbukaan Informasi Publik pada Dinas Kominfo Kota Tasikmalaya. Jurnal Komunikasi, 
12(2), 127-140. Retrieved from https://journal.uii.ac.id/jurnalkomunikasi/article/download/ 10967/8404

Moleong, L. J. (2010). Metodologi Penelitian Kualitatif (Edisi Revi). Bandung: PT. Remaja Rosdakarya.

Mustapa, Z. (2017). Bunga Rampai Birokrasi (Isu-isu Stratejik Seputar Birokrasi). Makassar: Celebes Media Perkasa.

Patarai, H. M. I. (2015). OMBUDSMAN dan Akuntabilitas: Perspektif Daerah Istimewa Yogyakarta. Makassar: De La Macca.

Setiaman, A., Sugiana, D., \& Narotama, J. (2013). Implementasi Kebijakan Keterbukaan Informasi Publik. Jurnal Kajian Komunikasi, 1(2), 196-205. Retrieved from http://jurnal.unpad.ac.id/jkk/ar ticle/view/6044

Setiawan, I. (2004). Rekonstruksi Birokrasi Pemerintahan Daerah. Sumedang: Institut Pemerintahan Dalam Negeri.

Sudharmono, J. (2004). Be G2C Good Governed Company: Panduan Praktis bagi BUMN untuk menjadi G2C-Good Governed Company dan Mengelolanya Berdasarkan Suara Hati. Jakarta: PT. Elex Media Komputindo.

Yusriadi. (2018). Reformasi Birokrasi dalam Pelayanan Publik. Yogyakarta: Deepublish. 